UDC 613.26-613.28

DOI: 10.21668/health.risk/2021.1.06.eng

Research article

\title{
ASSESSMENT AND CLASSIFICATION OF FOOD PRODUCTS AS PER HEALTH RISKS CAUSED BY CHEMICAL AND MICROBIOLOGICAL CONTAMINATION
}

\author{
O.G. Bogdanova ${ }^{1}$, O.A. Molchanova ${ }^{1,2}$, I.Yu. Tarmaeva ${ }^{3}$, N.V. Efimova ${ }^{1}$ \\ ${ }^{1}$ East-Siberian Institute of Medical and Ecological Research, 12a the 3rd micro-district, Angarsk, 665827, \\ Russian Federation \\ ${ }^{2}$ Federal Service for Surveillance over Consumer Rights Protection and Human Wellbeing, Buryatiya Region \\ office, 45b Klyuchevskaya Str., Ulan-Ude, 670013, Russian Federation \\ ${ }^{3}$ Federal Research Centre of Nutrition, Biotechnology and Food Safety, 2/14 Ustinsky lane, Moscow, 109240, \\ Russian Federation
}

Our research goal was to reveal priority food products (FP) distributed on a regional consumer market as per health risks they caused for population.

The research was accomplished with statistic, analytical, and mathematical procedures as well as using comparative analysis procedure.

We analyzed laboratory data on sanitary-chemical and physical-chemical parameters collected over 2010-2019; our analysis revealed there were insignificant risks excluding FP contamination with nitrates. Special attention should be paid to microbiological contamination as overall parameters related to it remain steady over the compared 5-year periods. We also have detected unfavorable trends as average parameters have grown authentically over the last 5 years against 2010-2014 when it comes to fruit and vegetables, poultry, fish products, and alcoholic beverages with growth rates varying from 3.53 times to 1.44 times.

Having accomplished all the necessary calculations, we established that in Buryatia, just as in the Russian Federation in general, there were no food products that could cause extremely high health risks. But at the same time, the examined regional market had certain differences from the overall Russian one. High health risks were caused by poultry and it was not the case in the country in general. Bakery, confectionary, and fish products that caused high health risks in the country as a whole caused only significant risks in the region. Milk products also were assigned into a high risk category. We performed complex assessment and classified FP as per their quality and safety using health risk analysis methodology; it allowed us to determine priorities resulted from microbiological contamination of poultry and this fact is vital for population health in Buryatia.

Key words: food products, chemical and microbiological contamination, quality and safety, health risk, classification, complex assessment, nutrition for population, regional peculiarities, Buryatia.

Protecting life and health of people who proprietors or juridical persons who deal with consume food products (FPs) should be given food products distribution. It is fixed in the last a priority over any economic interests of sole alterations to the Federal $\mathrm{Law}^{1}$ «On food

(C) Bogdanova O.G., Molchanova O.A., Tarmaeva I.Yu., Efimova N.V., 2021

Olga G. Bogdanova - Candidate of Medical Science, $\mathrm{PhD}$, senior researcher at the Laboratory for Ecological and Hygienic Research (e-mail: olga.bogdanova2001@gmail.com; tel.: +7 (3955) 58-69-10; ORCID: https://orcid.org/0000-0002-2358-2280).

Olga A. Molchanova - post-graduate student; Deputy Head of the Department for Supervision over Food Hygiene and Hygiene of Children and Adolescents (e-mail: olga_molchanova_1992@mail.ru; tel.: +7 (3955) 58-69-10; ORCID: https://orcid.org/0000-0002-5088-4794).

Inna Yu. Tarmaeva - Doctor of Medical Science, Professor, Academic Secretary, Leading Researcher at the Laboratory for Age-related Nutrition Studies (e-mail: t38_69@mail.ru; tel.: +7 (495) 698-53-42; ORCID: https://orcid.org/0000-0001-7791-1222).

Natalia V. Efimova - Doctor of Medical Science, Professor, Leading Researcher at the Laboratory for Ecological and Hygienic Research (e-mail: medecolab@inbox.ru; tel.: +7 (3955) 58-69-10; ORCID: https://orcid.org/0000-0001-7218-2147).

${ }^{1}$ On making alterations into the Federal law «On food products quality and safety» and into Clause 37 in the Federal Law «On education in the Russian Federation» No. 47-FZ issued on March 01, 2020. KonsultantPlus. Available at: http:// www.consultant.ru/document/cons_doc_LAW_346666/(30.09.2020) (in Russian). 
products quality and safety» and is a major principle of healthy nutrition [1-3]. An issue related to providing people with qualitative FPs is becoming more and more vital every year since its integral component, namely providing safety of food raw materials and finished products, is a basic factor that predetermines people's health and gene pool preservation. Required safety can be provided, among other things, via meeting Technical Regulations that are valid in the Customs Union and the Eurasian Economic Union [4-9].

Providing stability when it comes down to this factor is nowadays a most complicated and urgent task the civilization has to face and international organizations have to focus on [10]. Let us turn to certain official data provided by the WHO. In 2019 unsafe food products that contained malignant bacteria and carcinogens were estimated to cause more than 200 various diseases, from diarrhea to cancer. As per WHO estimates, 600 million people or almost each tenth person all over the world get sick after having consumed contaminated food products; 420 thousand people die annually due to food contamination and it results in 33 million years of health life being lost (DALY) [11].

Innovative technologies that are now used to produce and store FPs have substantially changed people's lifestyle and nutrition structure, first of all, in developed countries [12]. Nowadays people tend to consume more and more finished culinary products bought at catering facilities and in culinary shops; these food products are usually made according to strict technological and culinary procedures fixed for their cooking and storage; these technological processes and procedures involve substantial losses of essential (necessary) nutrients, first of all, certain vitamins and minerals as well as technical contaminants accumulating in food products [13]. In 2011, basic HACCP (Hazard Analysis and Critical Control Points) and a necessity to adhere to them were fixed in the EAEU legislation on technical regulation. But at the same time even when FPs manufacturing is controlled with HACCP princi- ples being used all the manufactured products can acquire certain properties during their distribution on consumer market that can be hazardous for people's health and may in future result on communicable and non-communicable diseases [14]. Studies that involved assessing whether food products conformed to sanitary-epidemiologic requirements and ranking food products as per potential health risks they might cause have been accomplished in Moscow, Perm region, Primorye, Samara region, Orenburg region, Voronezh region, Tatarstan, Bashkortostan, etc. [4, 15-20]. This situation is typical not only for Russia but also for such developed countries as Sweden, the USA, Italy, France, Germany, etc. Although consumers in these countries are offered quite a wide range of FPs, morbidity caused by contaminated FPs is also rather high there [21-31]. But still, we haven't been able to find any works that focused not only on determining regional peculiarities of food products contamination but also on further ranking hazards and potential health risks that might occur due to FPs consumption. Scientific substantiation provided for periodicity and necessary volumes of sampling during scheduled inspections is another vital practical task.

Aim, in this study, was to reveal priority food products as per health risks they cause for population due to microbiological and chemical contamination. As an example we took a region located in the Far East Federal District; the region was a border one and there were certain regional peculiarities in nutrition structure and food products contamination there.

Data and methods. Data on food products contamination were provided by regional information funds within social and hygienic monitoring system of Buryatiya Region office of Federal Service for Surveillance over Consumer Rights Protection and Human Wellbeing, and the Center for Hygiene and Epidemiology, Buryatiya Regional Office. We analyzed research results obtained in 2010-2019 via laboratory tests that were performed on 
157,440 food products samples collected randomly on consumer markets in Buryatiya. 89,921 samples were tested as per microbiological parameters; 27,266, sanitary-chemical ones; 16,460, parasitological ones; 17,974, physical and chemical ones; 1,204, radiological ones; 3,872 samples were tested to reveal any GMO traces in them, and 741 were tested in order to detect antibiotics in them. Results obtained via laboratory examinations were estimated according to the Customs Union Technical Regulations ${ }^{2,3,4,5,6}$. We calculated per cent and a share of examinations with results deviating from epidemiologic standards; shares were calculated from the overall number of examinations over each year and average value for 5-year periods (2010-2014 and 2015-2019).

Potential risks of damage to health due to people consuming specific food products (FPs) $\left(R_{\text {food }}^{1}\right)$ were calculated as per formulas $(1,2$, 3) basing on data obtained from state departmental statistical reports, Form No. 18 «Data on a sanitary situation in an RF region» (section 8 «Hygienic characteristics of food raw materials and food products», issued in Buryatiya in 2017-2019; and "Consumption of basic food products by the population in the RF» state bulletin, section with data on Buryatiya. Health risks were estimated according to the Methodical guidelines ${ }^{7}$.

$$
R_{\text {food }}^{1}=\sum_{i}\left(p_{i}^{1} \cdot u_{i}^{1}\right) \cdot W
$$

where $p_{i}^{1}$ is frequency (probability) that obligatory safety requirements to FPs will be violated as per i-th hazard factor during one inspection; $u_{i}^{1}$ is relative damage to health caused by violated sanitary-epidemiologic requirements to i-th hazard factor of FPs according to Appendix No. 3 to the Methodical guidelines;

$W$ is a coefficient that characterizes regional peculiarities related to various FPs consumption.

$$
p^{1}{ }_{i}=m_{i} / n_{i}
$$

where $m_{i}$ is a number of FPs examinations per year with results showing that $\mathrm{i}$-th factor deviates from the standards;

$n_{i}$ is an overall number of $\mathrm{i}$-th factor examinations per year.

$$
W=V / V_{\mathrm{RF}}
$$

where $V$ is actual annual FPs consumption per one person living in Buryatiya (kg/year, L/year, units/year);

$V_{\mathrm{RF}}$ is average annual FPs consumption per one person in Russia (kg/year, L/year, units/year).

Research results were statistically processed with «Statistica v. 10.0» software package according to conventional procedures. Results were given as simple means with $95 \%$ confidence interval (CI). Comparisons were accomplished as per Student's t-test for the above given 5-year periods.

Results and discussion. Over the analyzed period, namely 2010-2019, in Buryatiya a share of FPs deviating from hygienic standards as per microbiological parameters amounted to $4.06 \%$ on average $(3.86 ; 4.26)$; as per sanitary-chemical parameters, $4.71 \%$ $(4.09 ; 5.33)$; as per parasitological parame-

\footnotetext{
${ }^{2}$ CUTR 021/2011. On food products safety. KODEKS: an electronic fund for legal and reference documentation. Available at: http://docs.cntd.ru/document/902320560 (30.09.2020) (in Russian).

${ }^{3}$ CUTR 023/2011. Technical regulations for juice products made of fruit and vegetables. KODEKS: an electronic fund for legal and reference documentation. Available at: http://docs.cntd.ru/document/902320562 (30.09.2020) (in Russian).

${ }^{4}$ CUTR 024/2011. Technical regulations for butter and fat products. KODEKS: an electronic fund for legal and reference documentation. Available at: http://docs.cntd.ru/document/902320571 (30.09.2020) (in Russian).

${ }^{5}$ CUTR 033/2013. On safety of milk and milk products. KODEKS: an electronic fund for legal and reference documentation. Available at: http://docs.cntd.ru/document/499050562 (30.09.2020) (in Russian).

${ }^{6}$ CUTR 034/2013. On safety of meat and meat products. KODEKS: an electronic fund for legal and reference documentation. Available at: http://docs.cntd.ru/document/499050564 (30.09.2020) (in Russian).

${ }^{7}$ MR. Classification of food products distributed on the market as per risks of damage to health and property losses borne by consumers used for organizing scheduled control and surveillance activities. Approved by the Order issued by Rospotrebnadzor on January 18, 2016 No. 16. Available at: http://base.garant.ru/71313192/53f89421bbdaf741eb2d1ecc4ddb4c33/ (30.09.2020) (in Russian).
} 
ters, $0.10 \%(0.07 ; 0.14)$; as per physicalchemical parameters, $7.57 \%(6.92 ; 8.22)$; antibiotics, $0.40 \%(0.17 ; 0.64)$. Inspections didn't reveal any GMO contents exceeding $0.9 \%$ or radioactive substances in concentrations higher than hygienic standards. There was a stable number of FPs samples that didn't conform to relevant regulations (Table 1).

Overall, there were no statistical discrepancies in a number of FPs samples containing chemical or microbiological contaminants in 2015-2019 against 2010-2014 ( $p>0.05)$. The only exceptions were 2 parameters, namely, shares of FPs samples deviating from hygienic standards as per sanitary-chemical and physical-chemical parameters where statistical discrepancies were authentic $(p \leq 0.01)$.

When analyzing results of FPs assessment as per sanitary-chemical parameters over a 10 -year period, we revealed that a peculiar feature was FPs deviating from hygienic standards due to fruits and vegetables being contaminated with nitrates (potatoes, vegetables and melons). In 2010-2019 nitrates contents in these products were higher than hygienic standards on average in $5.55 \%$ (5.06; 6.05). Specific share of samples with elevated nitrates contents went down by 1.47 times in 2015-2019 against 2010-2014, from $6.37 \%(5.63 ; 7.12)$ to $4.32 \%(3.92$; 4.72); however, these discrepancies were not statistically significant $(p>0.05)$.

There were no FPs samples deviating from hygienic standards as per other sanitarychemical parameters detected over the analyzed period. The only exceptions were the last two years when inspections revealed sporadic elevated toxic $\mathrm{Pb}$ and $\mathrm{Cd}$ contents in FPs. Average value of this parameter amounted to $0.05 \%$ in 2010-2019. Sporadic deviations from hygienic standards were detected in 2018 in «biologically active additives» FPs category in 2018, $0.16 \%$ of the overall number of examined samples; in 2019 there were $0.15 \%$ samples of «milk and milk products» deviating from hygienic standards as per this parameter. Accordingly, these small values allow treating these revelations as «accidental ones».

There was 1.75 times decrease in a share of iodized salt with iodine contents being lower than stated by a manufacturer in 2015-2019 against 2010-2014; it amounted to $2.0 \%$ (1.85; $2.15)$ and $3.49 \%(29.2 ; 4.06)$ accordingly but discrepancies were not statistically significant $(p>0.05)$.

Table 1

Results of food products examinations in 2010-2019

\begin{tabular}{|c|c|c|c|c|}
\hline \multirow[t]{2}{*}{ Parameters } & \multicolumn{3}{|c|}{$\begin{array}{l}\text { Percent of samples deviating from hygienic standards } \\
\text { (simple means and CI), \% }\end{array}$} & \multirow{2}{*}{$\begin{array}{c}\text { Statistical } \\
\text { significance of } \\
\text { discrepancies }(p)\end{array}$} \\
\hline & $2010-2014$ & $2015-2019$ & $2010-2019$ & \\
\hline $\begin{array}{l}\text { Sanitary-chemical parameters } \\
\text { including }\end{array}$ & $\begin{array}{c}5.97 \\
(5.33 ; 6.61)\end{array}$ & $\begin{array}{c}2.57 \\
(2.43 ; 2.71) \\
\end{array}$ & $\begin{array}{c}4.71 \\
(4.09 ; 5.33)\end{array}$ & $p \leq 0.01$ \\
\hline $\begin{array}{l}\text { Heavy metals } \\
(\mathrm{Pb}, \mathrm{As}, \mathrm{Cd}, \mathrm{Hg})^{*}\end{array}$ & 0.00 & $\begin{array}{c}0.08 \\
(0.05 ; 0.12)\end{array}$ & $\begin{array}{c}0.05 \\
(0.01 ; 0.08)\end{array}$ & $p>0.05$ \\
\hline Iodine & $\begin{array}{c}3.49 \\
(2.92 ; 4.06)\end{array}$ & $\begin{array}{c}2.0 \\
(1.85 ; 2.15)\end{array}$ & $\begin{array}{c}2.79 \\
(2.49 ; 3.09)\end{array}$ & $p>0.05$ \\
\hline Nitrates & $\begin{array}{c}6.37 \\
(5.63 ; 7.12)\end{array}$ & $\begin{array}{c}4.32 \\
(3.92 ; 4.72)\end{array}$ & $\begin{array}{c}5.55 \\
(5.06 ; 6.05)\end{array}$ & $p>0.05$ \\
\hline Physical-chemical parameters & $\begin{array}{c}8.89 \\
(8.24 ; 9.55)\end{array}$ & $\begin{array}{c}5.43 \\
(5.21 ; 5.66)\end{array}$ & $\begin{array}{c}7.57 \\
(6.92 ; 8.22)\end{array}$ & $p \leq 0.01$ \\
\hline Microbiological parameters & $\begin{array}{c}3.98 \\
(3.67 ; 4.29)\end{array}$ & $\begin{array}{c}4.15 \\
(3.92 ; 4.38)\end{array}$ & $\begin{array}{c}4.06 \\
(3.86 ; 4.26)\end{array}$ & $p>0.05$ \\
\hline $\begin{array}{l}\text { Pathogenic microorganisms in- } \\
\text { cluding Salmonellas }\end{array}$ & $\begin{array}{c}0.17 \\
(0.13 ; 0.21)\end{array}$ & $\begin{array}{c}0.31 \\
(0.20 ; 0.41)\end{array}$ & $\begin{array}{c}0.23 \\
(0.13 ; 0.34)\end{array}$ & $p>0.05$ \\
\hline Parasitological parameters & $\begin{array}{c}0.18 \\
(0.12 ; 0.24)\end{array}$ & $\begin{array}{c}0.02 \\
(0.00 ; 0.05)\end{array}$ & $\begin{array}{c}0.10 \\
(0.07 ; 0.14)\end{array}$ & $p>0.05$ \\
\hline
\end{tabular}

$\mathrm{N}$ o t e : * means that examinations revealed Pband Cd contents. 
Over recent years closer attention has been paid to testing whether food products conform to requirements fixed in regulatory documents as per physical-chemical parameters. A specific share of FPs that deviated from hygienic standards as per this parameter amounted to $5.43 \%$ on average in 2015-2019 $(5.21 ; 5.66)$ and it was authentically 1.64 times lower than in previous 5 years when it amounted to $8.89 \%$ $(8.24 ; 9.55)(p \leq 0.01)$.

Microbiological FPs contamination didn't change in the compared periods. Thus, in 2010-2014 a share of FPs that deviated from hygienic standards as per microbiological parameters amounted to $3.98 \%(3.67 ; 4.29)$; in $2015-2019,4.15 \%(3.92 ; 4.38)$ and these discrepancies were not statistically significant $(p>0.05)$. High specific weight of FPs samples deviating from hygienic standards as per microbiological parameters was detected in several product groups over the examined years; thus, it amounted to $9.53 \%$ (8.76; 10.31 ) in «milk and milk products» group; $6.88 \%(5.96 ; 7.80)$; «fish, non-fish hunting objects and products made of them»; $6.21 \%$ $(3.25 ; 9.18)$, «fruits and vegetables»; $5.89 \%$ (4.98; 6.81), «alcoholic beverages»; $5.79 \%$ (5.52; 6.07), «bakery and confectionary»; $4.96 \%(4.72 ; 5.20)$, «meat and meat products»; $4.90 \%(3.96 ; 5.83)$, «poultry, eggs, and products made of them»; $3.32 \%(3.09 ; 3.55)$, «culinary products». Average parameters authentically increased in 4 FPs groups in the $2^{\text {nd }}$ period against the $1^{\text {st }} 5$ years, namely, they grew by 3.53 times in "fruits and vegetables» group; by 3.0 times, «poultry, eggs, and products made of them»; by 1.82 times, in «fish, non-fish hunting objects and products made of them» and «biologically active additives» (BAA) (Table 2). There was no authentically significant increase or decrease in other FPs groups.

There was a slight increase in a share of FPs samples that deviated from hygienic standards as per contents of pathogenic microorganisms over the analyzed period as it amounted to $0.31 \%(0.20 ; 0.41)$ in $2015-2019$ against $0.17 \%(0.13 ; 0.21)$ in $2010-2014$.

Table 2

Results of microbiological inspections of specific food product groups over 2010-2019

\begin{tabular}{|c|c|c|c|c|}
\hline \multirow{2}{*}{$\begin{array}{l}\text { Food raw materials } \\
\text { and food products }\end{array}$} & \multicolumn{3}{|c|}{$\begin{array}{l}\text { Percent of samples deviating from hygienic standards } \\
\text { (simple means and } \mathrm{CI} \text { ), \% }\end{array}$} & \multirow{2}{*}{$\begin{array}{l}\text { Statistical significance } \\
\text { of discrepancies }(p)\end{array}$} \\
\hline & $2010-2014$ & $2015-2019$ & $2010-2019$ & \\
\hline Meta and meat products & $\begin{array}{c}4.73 \\
(4.26 ; 5.20) \\
\end{array}$ & $\begin{array}{c}5.35 \\
(4.81 ; 5.89) \\
\end{array}$ & $\begin{array}{c}4.06 \\
(3.93 ; 4.19) \\
\end{array}$ & $p>0.05$ \\
\hline $\begin{array}{l}\text { Poultry, eggs, and products made } \\
\text { of them }\end{array}$ & $\begin{array}{c}2.52 \\
(1.94 ; 3.10)\end{array}$ & $\begin{array}{c}7.55 \\
(5.06 ; 10.04)\end{array}$ & $\begin{array}{c}4.90 \\
(3.96 ; 5.83)\end{array}$ & $p \leq 0.01$ \\
\hline Milk and milk products & $\begin{array}{c}10.56 \\
(8.52 ; 12.59)\end{array}$ & $\begin{array}{c}8.36 \\
(7.41 ; 9.30)\end{array}$ & $\begin{array}{c}9.53 \\
(8.76 ; 10.31)\end{array}$ & $p>0.05$ \\
\hline $\begin{array}{l}\text { Fish, non-fish hunting objects } \\
\text { and products made of them }\end{array}$ & $\begin{array}{c}5.25 \\
(4.37 ; 6.13) \\
\end{array}$ & $\begin{array}{c}9.55 \\
(7.19 ; 11.90) \\
\end{array}$ & $\begin{array}{c}6.88 \\
(5.96 ; 7.80) \\
\end{array}$ & $p \leq 0.01$ \\
\hline Bakery and confectionary & $\begin{array}{c}6.22 \\
(5.75 ; 6.70)\end{array}$ & $\begin{array}{c}5.12 \\
(4.51 ; 5.72) \\
\end{array}$ & $\begin{array}{c}5.79 \\
(5.52 ; 6.07)\end{array}$ & $p>0.05$ \\
\hline Fruits and vegetables & $\begin{array}{c}3.92 \\
(2.63 ; 5.21) \\
\end{array}$ & $\begin{array}{c}13.82 \\
(6.37 ; 21.27) \\
\end{array}$ & $\begin{array}{c}6.21 \\
(3.25 ; 9.18)\end{array}$ & $p \leq 0.01$ \\
\hline Culinary products & $\begin{array}{c}2.92 \\
(2.34 ; 3.49)\end{array}$ & $\begin{array}{c}3.48 \\
(3.11 ; 3.86)\end{array}$ & $\begin{array}{c}3.32 \\
(3.09 ; 3.55)\end{array}$ & $p>0.05$ \\
\hline Butter and fats & $\begin{array}{c}1.46 \\
(0.83 ; 2.10)\end{array}$ & $\begin{array}{c}2.51 \\
(1.67 ; 3.35)\end{array}$ & $\begin{array}{c}1.99 \\
(1.63 ; 2.35)\end{array}$ & $p>0.05$ \\
\hline Alcoholic beverages & $\begin{array}{c}4.97 \\
(3.56 ; 6.37) \\
\end{array}$ & $\begin{array}{c}7.14 \\
(4.85 ; 9.44) \\
\end{array}$ & $\begin{array}{c}5.89 \\
(4.98 ; 6.81) \\
\end{array}$ & $p>0.05$ \\
\hline Non-alcoholic beverages & $\begin{array}{c}0.84 \\
(0.65 ; 1.04)\end{array}$ & $\begin{array}{c}1.93 \\
(0.90 ; 2.95)\end{array}$ & $\begin{array}{c}1.17 \\
(0.82 ; 1.53) \\
\end{array}$ & $p>0.05$ \\
\hline BAA & 0 & $\begin{array}{c}3.18 \\
(1.36 ; 5.0)\end{array}$ & $\begin{array}{c}2.81 \\
(-1.09 ; 6.71)\end{array}$ & $p \leq 0.01$ \\
\hline
\end{tabular}


Table 3

Dependence between percentage of non-standard samples and a number of observations by parameters (in 2010-2019)

\begin{tabular}{|l|c|c|c|}
\hline \multicolumn{1}{|c|}{ Parameters $(y)$} & $\begin{array}{c}\text { Dependence on a number } \\
\text { of examinations }(x)\end{array}$ & Approximation coefficient & $p$ \\
\hline Sanitary-chemical & $y=0.09 x-126.55$ & $R^{2}=0.89$ & $=0.32$ \\
\hline Physical-chemical & $y=0.12 x-86.47$ & $R^{2}=0.85$ & $=0.33$ \\
\hline Microbiological & $y=0.03 x+75.08$ & $R^{2}=0.24$ & $=0.10$ \\
\hline Salmonella* & $y=0.9928 x-0.2543$ & $R^{2}=0.99$ & $=0.35$ \\
\hline Parasitological & $y=0.01 x-18.35$ & $R^{2}=0.37$ & $=0.02$ \\
\hline
\end{tabular}

$\mathrm{N}$ o t e : * means a number among FP samples containing pathogenic microorganisms in elevated quantities deviating from hygienic standards.

5 FPs groups were the most hazardous in this respect as they contained pathogenic microorganisms in quantities being higher than hygienic standards. These groups were «poultry, eggs, and products made of them», $3.77 \%$ (2.81; 4.73); «fruits and vegetables», $1.62 \%$ $(-2.51 ; 5.75)$; «meat and meat products», $0.85 \%(0.76 ; 0.94)$; «culinary products», $0.07 \%(0.05 ; 0.09)$; «bakery and confectionary», $0.05 \%(0.04 ; 0.07)$.

We analyzed dynamics in these parameters and revealed an increase in a share of FPs samples with pathogenic microorganisms' contents deviating from hygienic standards in 2015-2019 against the previous 5 years. The greatest increase was revealed in «poultry, eggs and products made of them» FPs group and amounted to 3.5 times. A share of such samples grew from 0 to $6.78 \%$ in «fruits and vegetables» FPs group. The situation with pathogenic microorganisms was rather stable in «meat and meat products» FPs group and «culinary products» FPs group and there were no authentic discrepancies between the compared periods: $0.77 \%(0.64 ; 0.89)$ in $2010-2014$ and $1.0 \%$ $(0.76 ; 1.23)$ in $2015-2019 ; 0.06 \%(0.01$; $0.11)$ in $2010-2014$ and $0.08 \%(0.04 ; 0.12)$ in 2015-2019 accordingly.

It was established that in 2015-2019 a share of FPs that contained salmonella amounted for $99.17 \%(98.73 ; 99.60)$ among FPs samples with detected pathogenic microorganisms in them that were not allowed according to hygienic standards; it was higher than the same parameter in 2010-2014 when it amounted to $96.34 \%(94.71 ; 97.98)$.

We applied linear approximation to analyze results obtained via FPs examinations aimed at revealing their conformity with hygienic standards as per sanitary-chemical, microbiological, parasitological, and physical-chemical parameters in 2010-2019. It allows predicting frequency of non-standard samples. As it is shown in Table 3, approximation coefficient is close to 1.0 for sanitary-chemical and physical-chemical parameters and it indicates that the more FPs samples are examined the more samples that deviate from hygienic standards are to be expected.

In its turn $R^{2}=0.24$ and 0.37 for microbiological and parasitological parameters accordingly and it means there is no such dependence. It confirms that detection of FPs samples that deviate from hygienic standards as per microbiological and parasitological parameters depends not only on overall number of FPs examinations as per these parameters. We can predict that a further growth in a number of examinations aimed at estimating FPs as per these criteria during scheduled inspections will not result in more frequently detected violations of hygienic requirements. Approximation coefficient is practically equal to 1.0 for salmonella detection. It means there is a direct correlation with a greater number of FPs samples containing pathogenic microorganisms in quantities deviating from hygienic standards and we can predict more fre- 
quent detection of samples containing this pathogen.

Our next task was to assign FPs to a certain category as per risks of causing damage to consumers' health taking into account regional peculiarities regarding food consumption. To do that, we calculated risks of damage to health due to people consuming food products that didn't conform to safety requirements. The results are given in Table 4 and compared with data obtained for the country as a whole [14].

These data indicate that risks associated with chemical contamination are insignificant excluding FPs contamination with nitrates. When it comes down to microbiological contamination, there seems to be a stable situation with it on the consumer market in Buryatiya but in spite of it certain FPs groups are to be paid closer attention, namely «poultry, eggs and products made of them» and «fruits and vegetables». There was a 3.5 times growth, fromc $1.75 \cdot 10^{-2}$ in $2010-2014$ to $6.12 \cdot 10^{-2}$ in 2015-2019 in average probability that obligatory safety requirements to poultry products might be violated due to elevated quantities of pathogenic microorganisms; the same parameters grew also for fruit and vegetables, from 0 to $6.78 \cdot 10^{-2}$ accordingly. Our analysis of approximation coefficients allowed us to predict greater frequency of detected salmonella due to growth in number of FPs samples containing pathogenic microorganisms in quantities exceeding hygienic standards.

We should note that there was a change in the structure of detected serologic salmonella types over the second 5-year period as there was a slight growth in quantity of detected salmonella belonging to group $\mathrm{S}$ (S. Infantis). It is well in line with data obtained by P. Antunes [et al.] on a significant decrease in S. Enteritidis quantities and a growing number of serotypes that are more adaptable and more resistant to antibiotics, such as S. Infantis, S. Kentucky etc. [32]. But at the same time, according to data given by T. Oscar in a model he developed, prevalence of salmonella didn't correlate $(r=-0.39 ; p=0.21)$ with a risk that salmonellosis might occur. That risk was influenced by other factors such as quantity of salmonella; their virulence; how often and to what extent poultry meat was poorly cooked;

Table 4

Classification of food products, according to health risks due to consumption by the population living in Republic of Buryatiya

\begin{tabular}{|c|c|c|c|c|}
\hline \multirow[b]{2}{*}{$\begin{array}{l}\text { Food products } \\
\text { group }\end{array}$} & \multicolumn{3}{|c|}{ Buryatiya } & \multirow[b]{2}{*}{$\begin{array}{l}\text { Potential health risk cate- } \\
\text { gory / Hazard category for } \\
\text { damage to health in the } \\
\text { Russian Federation [14] }\end{array}$} \\
\hline & $\begin{array}{l}\text { coefficient that char- } \\
\text { acterizes regional } \\
\text { consumption }(W)\end{array}$ & $\begin{array}{l}\text { potential } \\
\text { health } \\
\text { risk }(R)\end{array}$ & $\begin{array}{l}\text { Potential health risk cate- } \\
\text { gory / Hazard category } \\
\text { for damage to health } \\
\text { in the examined region }\end{array}$ & \\
\hline $\begin{array}{l}\text { Poultry, eggs and } \\
\text { products made of them }\end{array}$ & 0.88 & $1.54 \cdot 10^{-2}$ & High / 2 category & Significant / 3 category \\
\hline Bakery and confectionary & 1.16 & $3.97 \cdot 10^{-3}$ & Significant / 3 category & High / 2 category \\
\hline Fish and fish products & 0.91 & $2.82 \cdot 10^{-3}$ & Significant / 3 category & High / 2 category \\
\hline Milk and milk products & 0.78 & $1.58 \cdot 10^{-3}$ & Significant / 3 category & Significant / 3 category \\
\hline Meat and meat products & 0.75 & $7.21 \cdot 10^{-5}$ & Average / 4 category & Significant / 3 category \\
\hline Potato & 1.44 & $2.76 \cdot 10^{-4}$ & Average / 4 category & Moderate / 5 category \\
\hline Culinary products* & 0.94 & $2.46 \cdot 10^{-4}$ & Average / 4 category & Significant / 3 category \\
\hline Butter and fats & 0.80 & $2.17 \cdot 10^{-4}$ & Average / 4 category & Moderate / 5 category \\
\hline Vegetables & 0.70 & $1.30 \cdot 10^{-5}$ & Moderate / 5 category & Moderate / 5 category \\
\hline Canned food* & 1.0 & $1.44 \cdot 10^{-5}$ & Moderate / 5 category & Significant / 3 category \\
\hline $\mathrm{BAA}^{*}$ & 0.70 & $1.41 \cdot 10^{-5}$ & Moderate / 5 category & Moderate / 5 category \\
\hline
\end{tabular}

$\mathrm{N}$ ot e : * means that $\mathrm{R}$ as potential health risk caused by people consuming a specific food product is calculated as per mean values obtained from Section 8 in the Statistical Report Form No. 18 over 2017-2019. 
consumer behavior when cooking and eating poultry meat; and a particular person's resistance to the pathogen. All this combined determines a necessity to apply a more integral approach involving technological and behavioral risks assessment and is in line with data obtained by E. Lambertinia [et al.], Y. Cui [et al.] [33-35].

Having calculated potential health risks caused by people consuming a specific food products we established that there were no food products categorized as extremely risky in Buryatiya, just as it was the case with the country in general [14]. But still, there were certain difference detected on the regional consumer market against the data obtained for the country as a whole. Thus, «poultry, eggs and products made of them» FPs group caused high health risks due to microbiological contamination with pathogens (detected salmonella), whereas there were no such risks detected in the country on average. Given that, this product group is subject to obligatory control in $100 \%$ cases as per a list of factors determined via previous inspections performed at economic entities. Bakery and confectionary, fish and fish products that were determined as causing high health risks in the Russian Federation caused only significant health risks on the examined regional market. Besides, significant risks were caused by «milk and milk products» FPs group. Average risks that required control in $50 \%$ cases during scheduled inspections performed at economic entities included such FPs groups as «meat and meat products», «potato», «butter and fats», and «culinary products». According to calculated data, vegetables, canned food and BAA cause only moderate risks and require control in $10 \%$ cases. The remaining products groups caused low health risks and were assigned into FPs category that required only documentary control in case there were time and labor resources to perform it.

Conclusion. We accomplished complex assessment of FPs quality and safety; it allowed us to classify food products as per health risks they caused with determining certain priorities. The results are vital for public health preservation in Buryatiya. In case there is a growth in number of targeted FPs examinations, we predict more frequently detected violations of hygienic requirements as per sanitary-chemical and physical-chemical parameters. The greatest health risk for population is caused by microbiological contamination of poultry products distributed on the regional market.

Given that, it is necessary to continue monitoring activities together with veterinary services aimed at providing food products safety and animals' health; it is also necessary to pursue a «restraining strategy» aimed at minimizing microbiological contamination and reducing salmonella transfer along food chains (from primary manufacture to consumption).

Food products trade on the global scale involves growing consumer demand for poultry meat on regional markets, especially in countries with low and middle incomes. This, together with this products being widely promoted by mass media, can make for low quality and potentially hazardous products penetrating the consumer market in Buryatiya; in future it can result in a deteriorating epidemiological situation.

Funding. The present work was accomplished within a budgetary scientific research program.

Conflict of interest. The authors declare there is no any conflict of interests.

\section{References}

1. Tutel'yan V.A., Nikityuk D.B., Sharafetdinov Kh.Kh. Zdorovoe pitanie - osnova zdorovogo obraza zhizni i profilaktiki khronicheskikh neinfektsionnykh zabolevanii [Healthy nutrition as a basis for healthy lifestyle and prevention of chronic non-communicable diseases]. Zdorov'e molodezhi: 
novye vyzovy i perspektivy. Moscow, OOO IPTs Nauchnaya kniga Publ., 2019, pp. 203-227 (in Russian).

2. Popova A.Yu., Gurvich V.B., Kuz'min S.V., Mishina A.L., Yarushin S.V. Modern issues of the health risk assessment and management. Gigiena i sanitariya, 2017, vol. 96, no. 12, pp. 1125-1129 (in Russian).

3. Bertolatti D., Theobald C. Food safety and risk analysis. Encyclopedia of Environmental Health, 2019, pp. 57-67. DOI: 10.1016/B978-0-12-409548-9.11821-4

4. Sazonova O.V., Gorbachev D.O., Nurdina M.S., Kupaev V.I., Borodina L.M., Gavryushin M.Yu., Frolova O.V. Hygienic characteristics of actual nutrition of the working population Samara region. Voprosy pitaniya, 2018, vol. 87, no. 4, pp. 32-38 (in Russian).

5. Belova L.V., Pil'kova T.Yu., Fedotova I.M. Obespechenie kachestva i bezopasnosti pishchevykh produktov $\mathrm{v}$ nastoyashchii period [Providing quality and safety of food products nowadays]. Zdorov'e - osnova chelovecheskogo potentsiala: problemy i puti ikh resheniya, 2018, no. 2, pp. 754-759 (in Russian).

6. Litvinova O.S. Hygienic assessment of nutrition structure of population of the Russian Federation. Zdorov'e naseleniya i sreda obitaniya, 2016, vol. 278, no. 5, pp. 11-14 (in Russian).

7. Baglushkina S.Yu., Efimova N.V., Tarmaeva I.Yu. The structure of the adult nutrition and risk of illness connected with infrigement of nutrition. Zdorov'e naseleniya i sreda obitaniya, 2015, vol. 267, no. 6, pp. 23-25 (in Russian).

8. Mozaffarian D. Dietary and Policy Priorities for Cardiovascular Disease, Diabetes, and Obesity: A Comprehensive Review. Circulation, 2016, vol. 2, no. 133, pp. 187-225. DOI: 10.1161/CIRCULATIONAHA.115.018585

9. Shur P.Z., Zaitseva N.V., Khotimchenko S.A., Fedorenko E.V., Sychik S.I., Fokin V.A., Suvorov D.V., Zelenkin S.E. On the issue of establishing acceptable daily intake of chemical substances in food products according to health risk criteria. Gigiena i sanitariya, 2019, vol. 98, no. 2, pp. 189-195 (in Russian).

10. Serafimovich A.E., Prosekov A.Yu. Food security: international legal aspects and Russian law enforcement practice. Pravo. Zhurnal Vysshei shkoly ekonomiki, 2018, no. 4, pp. 235-253 (in Russian).

11. WHO. News bulletin. August 2019. Food safety. Social aspects of public health. Available at: https://cyberleninka.ru/article/n/voz-informatsionnyy-byulleten-avgust-2019-bezopasnost-produktov-pitaniya (30.09.2020).

12. Song Y.-H., Yu H.-Q., Tan Y.-C., Lv W., Fang D.-H., Liu D. Similarity matching of food safety incidents in China: Aspects of rapid emergency response and food safety. Food Control, 2020, no. 115 , pp. 107275 . DOI: $10.1016 /$ j.foodcont.2020.107275

13. Poznyakovskii V.M. Nutrition evolution and nutriom formation of the modern human. Food industry, 2017, vol. 4, no. 3, pp. 5-12 (in Russian).

14. Zaitseva N.V., Ustinova O.Yu., Sboev A.S. Medical and preventive technologies for risk management of health problems associated with exposure to environmental factors. Gigiena $i$ sanitariya, 2016, vol. 95, no. 1, pp. 17-22 (in Russian).

15. Andreeva E.E. Application of a risk-oriented model for the redistribution of staffing resources of the office of service for supervision of consumer rights protection and human welfare in the city of Moscow. Gigiena i sanitariya, 2018, vol. 97, no. 5, pp. 441-444 (in Russian).

16. Kislitsyna L.V. Assessment of the potential risk of harm to health due use community food for the Primorsky region of Russia. Zdorov'e. Meditsinskaya ekologiya. Nauka, 2016, vol. 66, no. 3, pp. 188-192 (in Russian).

17. Boev V.M., Borshchuk E.L., Kryazhev D.A., Savina E.K. Malignant tumors of the rectum, rectosigmoid connections and colon and hygienic evaluation of carcinogenic chemicals entering the oral route. Zdorov'e naseleniya i sreda obitaniya, 2017, vol. 291, no. 6, pp. 13-17 (in Russian).

18. Klepikov O.V., Khatuaev R.O., Istomin A.V., Rumyantseva L.A. Regional features of food standards and health risks associated with chemical contamination of food. Gigiena i sanitariya, 2016, vol. 95, no. 11, pp. 1086-1091 (in Russian). 
19. Mukhutdinova G.M., Mukhametshin I.R., Patyashina M.A., Avdonina L.G., Rybachenok T.M., Filippova S.Yu., Imamov A.A. The role of food to achieve optimal health. Sciences of Europe, 2018, vol. 28, no. 1, pp. 19-24 (in Russian).

20. Daukaev R.A., Larionova T.K., Allayarova G.R., Adieva G.F., Afon'kina S.R., Fazlyeva A.S., Usmanova E.N., Kurilov M.V. Territories ranking of Bashkortostan on the level of food products contamination. Zdorov'e naseleniya i sreda obitaniya, 2019, vol. 310, no. 1, pp. 24-27 (in Russian).

21. Wallace T.C., Frankenfeld C.L., Frei B., Shah A.V., Yu C.R., Van Klinken B.J., Adeleke M. Multivitamin/multimineral supplement use is associated with increased micronutrient intakes and biomarkers and decreased prevalence of inadequacies and deficiencies in middle-aged and older adults in the United States. J. Nutr. Gerontol. Geriatr., 2019, vol. 4, no. 38, pp. 307-328. DOI: 10.1080/21551197.2019.1656135

22. Yasuda H., Tsutsui M., Ando J., Inano T., Noguchi M., Yahata Y., Tanaka M. [et al.]. Vitamin B6 deficiency is prevalent in primary and secondary myelofibrosis patients. Int. J. Hematol., 2019, vol. 5, no. 110 , pp. 543-549. DOI: 10.1007/s12185-019-02717-8

23. Tarmaeva I.Yu., Efimova N.V., Khankhareev S.S., Bogdanova O.G. Features of actual nutrition of the adult population in republic of Buryatia in modern conditions. Voprosy pitaniya, 2018, vol. 87, no. 3, pp. 30-35 (in Russian).

24. Lappi V.M., Mottas A., Sundstrom J., Neal B., Lof M., Radholm K. A Comparison of the nutritional qualities of supermarket's own and regular brands of bread in Sweden. Nutrients, 2020, vol. 2, no. 4, pp. 1162. DOI: 10.3390/nu12041162

25. Melotto M., Brandl M.T., Jacob C., Jay-Russell M.T., Micallef S.A., Warburton M.L., Van Deynze A. Breeding crops for enhanced food safety. Frontiers in plant science, 2020, no. 11, pp. 428. DOI: $10.3389 /$ fpls.2020.00428

26. Iannetti L., Schirone M., Neri D., Visciano P., Acciari V.A., Centorotola G., Mangieri M.S. [et al.]. Listeria monocytogenes in poultry: Detection and strain characterization along an integrated production chain in Italy. Food microbiology, 2020, no. 91, pp. 103533. DOI: 10.1016/j.fm.2020.103533

27. Di Bella C., Traina A., Giosue C., Carpintieri D., Lo Dico G.M., Bellante A., Del Core M. [et al.]. Heavy metals and PAHs in meat, milk, and seafood from augusta area (southern Italy): contamination levels, dietary intake, and human exposure assessment. Frontiers in public health, 2020, no. 8, pp. 273. DOI: 10.3389/fpubh.2020.00273

28. Srour B., Fezeu L.K., Kesse-Guyot E., Alles B., Mejean C., Andrianasolo R.M., Chazelas E. [et al.]. Ultra-processed food intake and risk of cardiovascular disease: prospective cohort study (NutriNet-Sante). BMJ, 2019, vol. 29, no. 365, pp. 11451. DOI: 10.1136/bmj.11451

29. Gerson J.R., Driscoll C.T., Demers J.D., Sauer A.K., Blackwell B.D., Montesdeoca M.R., Shanley J.B., Ross D.S. Deposition of mercury in forests across a montane elevation gradient: Elevational and seasonal patterns in methylmercury inputs and production. Journal of geophysical researchbiogeosciences, 2017, vol. 8, no. 122, pp. 1922-1939. DOI: 10.1002/2016JG003721

30. Shariatifar N., Seilani F., Jannat B., Nazmara S., Arabameri M. The concentration and health risk assessment of trace elements in commercial soft drinks from Iran marketed. International journal of environmental analytical chemistry, 2020, $16 \mathrm{p}$.

31. Carraturo F., Libralato G., Esposito R., Galdiero E., Aliberti F., Amoresano A., Fontanarosa C., Trifuoggi M., Guida M. Metabolomic profiling of food matrices: Preliminary identification of potential markers of microbial contamination. Journal of food science, 2020, vol. 10, no. 85, pp. 3467-3477. DOI: 10.1111/1750-3841.15418

32. Antunes P., Mourao J., Campos J., Peixe L. Salmonellosis: the role of poultry meat. Clinical microbiology and infection, 2016, no. 22, pp. 110-121. DOI: 10.1016/j.cmi.2015.12.004

33. Oscar T. Salmonella prevalence alone is not a good indicator of poultry food safety. Risk analysis, 2020, no. 10, pp. 1111. DOI: 10.1111/risa.13563

34. Lambertini E., Ruzante J.M., Chew R., Apodaca V.L., Kowalcyk B.B. The public health impact of different microbiological criteria approaches for Salmonella in chicken parts. Microbial Risk Analysis, 2019, no. 12, pp. 44-59. DOI: 10.1016/j.mran.2019.06.002 
35. Cui Y., Guran H.S., Harrison M.A., Hofacre C.L., Alali W.Q. Salmonella levels in turkey neck skins, drumstick bones and spleens in relation to ground turkey. Journal of food protection, 2015, vol. 11, no. 78, pp. 1945-1953. DOI: 10.4315/0362-028X.JFP-15-240

Bogdanova O.G., Molchanova O.A., Tarmaeva I.Yu., Efimova N.V. Assessment and classification of food products as per health risks caused by chemical and microbiological contamination. Health Risk Analysis, 2021, no. 1, pp. 57-67. DOI: 10.21668/health.risk/2021.1.06.eng

Received: 22.10 .2020

Accepted: 07.02.2021

Published: 30.03.2021 